\title{
Koncepcja usieciowienia jako etyczny klucz interpretacyjny zasady zrównoważonego rozwoju
}

\author{
kukasz Marczak \\ Instytut Pracy Socjalnej, Uniwersytet Papieski Jana Pawła II w Krakowie \\ ul. Bernardyńska 3/60, 31-069 Kraków \\ lukanm3@gmail.com•0RCID: 0000-0003-1553-1747
}

\begin{abstract}
Streszczenie
Celem opracowania jest przedstawienie wypracowanej na gruncie chrześcijańskiej etyki społecznej koncepcji usieciowienia (Retinität), która stała się kluczem interpretacyjnym zasady zrównoważonego rozwoju. Artykuł prezentuje usieciowienie w ujęciu monachijskiego etyka społecznego Markusa Vogta uznającego tę koncepcję w chrześcijańskiej etyce społecznej za fundamentalną strategię działania na rzecz ochrony środowiska przyrodniczego. Koncepcja Retinität stała się jednym z uwarunkowań zasady zrównoważonego rozwoju wyłonionej na gruncie katolickiej nauki społecznej w wyniku analizy systemu zasad etyczno-społecznych sformułowanego przez przedstawiciela Lubelskiej Szkoły Katolickiej Nauki Społecznej Władysława Piwowarskiego.
\end{abstract}

\section{Słowa klucze}

usieciowienie, zrównoważony rozwój, katolicka nauka społeczna, chrześcijańska etyka społeczna

\section{Wstęp}

Niektóre modele etyk ekologicznych nie chronią dostatecznie statusu człowieka w świecie stworzonym, co więcej, są nawet względem niego destrukcyjne (Marx, Wulsdorf 2002: 334-339). Wskutek dynamicznie zmieniającej się kwestii społecznej i coraz większej ekspansji człowieka w środowisko naturalne wyłaniająca się wyraźnie od lat 70. XX w. kwestia ekologiczna stała się impulsem do przemyślenia na nowo nie tylko odniesienia człowieka do środowiska przyrodniczego (Mariański, 2003: 202-218), lecz także wzajemnej relacji społeczeństwa ze środowiskiem naturalnym (Becker, Jahn 2006). W tle normy sprawiedliwości społecznej ujawnia się wciąż potrzeba etycznej interpretacji współczesnych koncepcji rozwoju społeczno-gospodarczego, wśród których, w ostatnich latach, jedną z najbardziej rozwijanych idei jest koncepcja zrównoważonego rozwoju stawiająca m.in. za cel przemianę stylu życia według nowych paradygmatów uwzględniających wysoką wartość nie tylko życia ludzkiego, lecz także środowiska przyrodniczego.

W związku z wieloznacznością definicyjną kategorii zrównoważony rozwój w artykule pomija się ten problem i przyjmuje się klasyczną definicję zrównoważonego rozwoju, który rozumie się jako rozwój współczesnych społeczeństw polegający 
na zaspokojeniu ich potrzeb w taki sposób, aby nie zmniejszać możliwości zaspokajania potrzeb przyszłym pokoleniom ( $\mathrm{Ra}$ port Brundtland 1987: 27). Tak rozumiany zrównoważony rozwój zakłada realizację wymogu sprawiedliwości społecznej - zarówno w zakresie wewnątrzpokoleniowym, jak i w perspektywie przyszłych pokoleń poprzez wzajemną integrację systemu społecznego, gospodarczego i ekologicznego.

Celem opracowania jest przedstawienie zarysu wypracowanej na gruncie chrześcijańskiej etyki społecznej koncepcji usieciowienia (Retinität), która stała się kluczem interpretacyjnym zasady zrównoważonego rozwoju na gruncie chrześcijańskiej etyki społecznej (Vogt 2009: 349, 357). Artykuł prezentuje usieciowienie w ujęciu monachijskiego etyka społecznego Markusa Vogta, który uznaje tę koncepcję za fundamentalną strategię działania na rzecz ochrony środowiska naturalnego i istotny element etyki ekologicznej.

\section{Kontekst usieciowienia - uniwersalna solidarność}

Zdaniem Andreasa Lienkampa idea usieciowienia przypomina rozwinięcie wykładni solidarności i jej dwóch wymiarów opracowanych przez Oswalda von Nell-Breuninga, który przy solidarności rozróżnił zasadę bytu - socjologicznie odkryty fakt, prawdziwy stan faktyczny (Gemeinverstrickung) - od zasady powinności - normatywnego orzeczenia, wymogu etycznego (Gemeinverhaftung). Solidarność jest nie tylko kategorią deskryptywną, lecz także kategorią preskryptywną - określa powinność zachowania. „Solidarność w takim ujęciu jest pojęciem normatywnym o bezwarunkowym i uniwersalnym charakterze" (Nell-Breuning 1985: 54). Z tego uniwersalnego rozumienia wynika, że troska solidarności nie kończy się tylko w granicach rodziny czy grona przyjaciół, wspólnot lokalnych, narodowych czy ludzi obecnie żyjących. Uniwersalność solidarności wskazuje także na odpowiedzialność za przyszłe pokolenia (Lienkamp 2009: 291). Zgodnie z teorią Adwokatenplanung
Dietera Birnbachera także ludzie współcześnie żyjący są odpowiedzialni za nieobecne jeszcze pokolenia, których interesy już dziś można chronić i reprezentować. To szczególne przedstawicielstwo dotyczy nie tylko osób jeszcze niezaistniałych, lecz także ich naturalnego środowiska, które bogate w zasoby będzie warunkować ich życie i szanse rozwoju (Birnbacher 2009: 98). Choć odpowiedzialność międzypokoleniowa dotyczy szeregu dylematów i kontrowersji, wydaje się, że rozwój przyszłych pokoleń będzie uzależniony od stopnia innowacyjności technologii wykorzystywania zasobów naturalnych i etyk szczegółowych uzasadniających ich użytkowanie (Vogt 2009 386-391). Nie można przy tym zapomnieć o rozumieniu solidarności jako mocnego i trwałego angażowania się na rzecz dobra wspólnego, które jest kluczową kategorią personalizmu chrześcijańskiego afirmującego godność osoby ludzkiej.

\section{Usieciowienie jako strategia ochrony środowiska naturalnego}

Pojęcie usieciowienia (Retinität) ${ }^{1}$ ukształtował Wilhelm Korff ${ }^{2}$ i jako przewodnią normę działania po raz pierwszy zaprezentował w 1989 r. na łamach czasopisma "Stimmen der Zeit" (Korff 1989: 258). W tym pojęciu autor przedstawił nowe wyzwania stojące przed gospodarką, która powinna być bardziej ukierunkowana na ochronę środowiska

1 Usieciowienie w języku niemieckim przedstawia się za pomocą dwóch pojęć: Vernetzung i Retinität. Vernetzung oznacza ogólnie rozumianą sieciowość, natomiast Retinität zyskało bardziej charakter etyczny, zwłaszcza po 1994 r., kiedy koncepcja usieciowienia została zaakceptowana przez Radę Ekspertów ds. Środowiska Naturalnego przy Bundestagu.

2 Wilhelm Korf (ur. 1926) - profesor chrześcijańskiej etyki społecznej na Ludwig-Maximilians-Universität w Monachium (od 1979), wcześniej pracował na Uniwersytecie w Tübingen (1973-1979), współwydawca pierwszego ekumenicznego podręcznika do etyki chrześcijańskiej (1979-1982), członek Rady Ekspertów ds. Środowiska Naturalnego przy Bundestagu (1991-1996), od 1993 r. na emeryturze. 
naturalnego (Korff 1991: 9-36, za: Vogt 1999: 246). W opinii etyka społecznego Bernharda Sutora usieciowienie jest ideą cyrkulacyjnego, połączonego myślenia i działania w obliczu uwarunkowań czynników ekonomicznych, ekologicznych, społeczno-kulturowych i politycznych (Sutor 2012: 620).

Wydaje się, że centralną intencją ukształtowania pojęcia usieciowienia było przeniesienie specyficznie międzyludzkiego pojęcia solidarności na etyczną interpretację płaszczyzny: człowiek-środowisko naturalne. Koncepcja usieciowienia nie opisuje tylko autentycznego stanu faktycznego, lecz zawiera również powinność etyczną. Usieciowienie żąda koniecznego do zachowania życia połączenia zwrotnego wszystkich procesów społecznych z ogromną dynamiką procesów gospodarczych, przy zachowaniu zdolności reprodukcyjnej środowiska naturalnego (Vogt 1998: 209).

Nowa teoria Wilhelma Korffa, rozwinięta dalej przez Markusa Vogta ${ }^{3}$, w 1994 r. została zaakceptowana przez Radę Ekspertów ds. Środowiska Naturalnego przy Bundestagu. Eksperci nazwali usieciowienie kluczową zasadą ochrony środowiska naturalnego i uznali, że ta zasada mogłaby stać się decydującą wielkością regulacyjną w ochronie środowiska naturalnego. Przy tym mogłaby zapisać się jako najważniejszy element, a jednocześnie sedno kompleksowej etyki środowiska naturalnego: jeśli człowiek, jako istota rozsądna, chce zadbać o swoją godność w stosunku do siebie samego i innych stworzeń, tylko wtedy może sprawiedliwie urzeczywistnić odpowiedzialność za środowisko naturalne, kiedy rozważnie będzie

3 Markus Vogt (ur. 1962) - profesor chrześcijańskiej etyki społecznej w Ludwig-Maximilians-Universität w Monachium (od 2007), wcześniej wykładowca w Salezjańskiej Wyższej Szkole Filozoficzno-Teologicznej w Benediktbeuern (1998-2007), członek Rady Ekspertów ds. Środowiska Naturalnego przy Bundestagu (1991-1995), członek zespołu ds. ochrony środowiska przy Konferencji Episkopatu Niemiec (od 1995), w chrześcijańskiej etyce społecznej twórca zasady zrównoważonego rozwoju (Nachhaltigkeitsprinzip). czynił zasadą swojego działania wspólne połączenie wszystkich swoich działań z niosącą go przyrodą, od której w ostateczności i tak jest zależny (Deutscher Bundestag. 1994: 404-4.07).

Ważnym momentem w rozwoju idei usieciowienia był rok 1996. Wówczas Stowarzyszenie na Rzecz Ochrony Środowiska i Przyrody Niemiec wraz z Biskupim Dziełem Pomocy Misereor przedstawiło studium nt. ochrony środowiska Przyszła zdolność Niemiec. W programie globalnego zrównoważonego rozwoju, obok zasady solidarności i zasady pomocniczości, ukazano w randze zasady społecznej wzór przewodni zrównoważonego rozwoju w sensie usieciowienia sfer społecznych, ekonomicznych i ekologicznych (Heimbach-Steins, Lienkamp, 2007: 463). W następnym roku Rada Kościoła Ewangelickiego w Niemczech i Konferencja Episkopatu Niemiec w dokumencie ekumenicznym Przyszłość $w$ solidarności i sprawiedliwości przedstawiły usieciowienie jako wzór przewodni idei zrównoważonego rozwoju, która w duchu solidarności i sprawiedliwości społecznej uwzględnia troskę nie tylko o dzisiejsze, lecz także o przyszłe pokolenia (Rat der Evangelischen Kirche... 1997: 122-125). Celem tej szczególnej integracji jest odpowiedzialne korzystanie z zasobów środowiska naturalnego. Niedługo potem, w 1998 r., w dokumencie Dziatanie dla przyszłości stworzenia znów przedstawia się zrównoważony rozwój w formie żądania realizacji odpowiedzialności za dzieło stworzenia. Również ten dokument przedstawia ideał etyczny zrównoważonego rozwoju w zasadzie usieciowienia, która zakłada zmianę paradygmatu postępu cywilizacyjnego. Szczegółowo wzór zrównoważonego rozwoju jest rozwijany w sensie społeczno-ekonomicznym uwzględniającym wysoką wartość środowiska naturalnego. $\mathrm{Na}$ tej podbudowie pokazuje się, jak zasada etyczna usieciowienia integruje się z etyką chrześcijańską, wchodząc w rozumienie antropocentrycznego modelu etyki ekologii. Pozostałe ekologiczne modele etyczne (fizjocentryczny, biocentryczny, patocentryczny, 
ekocentryczny) są nie do przyjęcia z punktu widzenia katolickiej nauki społecznej. Tylko teoria antropocentryczna w ochronie środowiska naturalnego, ze względu na górowanie człowieka względem całego stworzenia, gwarantuje mu nienaruszalny status w świecie stworzonym (Marx, Wulsdorf, 2002: 334-343). Zrównoważony rozwój zakłada zastosowanie kryteriów decyzyjnych, z których miałaby wynikać zmiana stylu życia poprzez kształtowanie świadomości ochrony środowiska naturalnego.

W nauczaniu społecznym biskupów Niemiec etyczny koncept usieciowienia wiąże się z nową orientacją celów współczesnych społeczeństw ze względu na coraz większą konieczność uwzględnienia problematyki ekologicznej. Ekonomiczne i społeczne mechanizmy konkurencji określiły rozwój tak bardzo, że przyspieszona ewolucja systemów ekonomicznych nie została dostatecznie zintegrowana z systemami ekologicznymi i ich dynamiką czasową. Ogólnie pozwala się opisywać ten podstawowy problem kryzysu ekologicznego jako niejednoczesność rozwoju społeczno-ekonomicznego ze zdolnością reprodukcyjną ekosystemów. Tego problemu dotyka m.in. idea zrównoważonego rozwoju, której istotnym żądaniem jest synchronizacja i usieciowienie społecznych, ekonomicznych i ekologicznych celów. Takie usieciowienie jest szczególnie konieczne, ponieważ chodzi przy tym o zarys problematyki ochrony środowiska naturalnego, której można sprostać tylko w intensywnej integracji zróżnicowanych fachowych dyscyplin, grup społecznych i instytucji (Die deutschen Bischöfe, 1998: 119-120).

\section{Definicja usieciowienia według Markusa Vogta}

W podręcznikach etyki gospodarki definicję usieciowienia najczęściej podaje się za M. Vogtem, który stwierdza, że usieciowienie pochodzi od łacińskiego terminu rete i oznacza sieć. Usieciowienie (Ratinität) jest, według niego, zasadą etyczną, której głównym żądaniem jest ukierunkowanie rozwoju cywilizacji ludzkiej w taki sposób, żeby pozostała zachowana sieć nośnych ekologicznie obwodów regulacyjnych. Zasada usieciowienia wychodzi od przedstawienia zarówno przyrody, jak i cywilizacji ludzkiej jako otwartych, dynamicznych systemów, przez co odsłania się inspiracja myśli $M$. Vogta w koncepcji systemów społecznych Niklasa Luhmanna (Vogt 2009: 355), od której katolicka nauka społeczna jest daleka. Kryterium orientacyjnym nie jest model środowiska naturalnego utrzymanego przez granicę wzrostu, lecz ideał dynamicznej stabilizacji kompleksowego związku człowieka ze środowiskiem naturalnym. Zasadnicze jest tutaj usieciowienie i rozwój współzależnych procesów społecznych, ekonomicznych i ekologicznych, przy czym zwraca się szczególną uwagę na krytyczne parametry działań wymiennych (Vogt 1998: 346; Keppeler 2014: 154). Centralną jednostką czy węzłem usieciowienia systemu społecznego, gospodarczego i ekologicznego jest osoba ludzka posiadająca niezbywalną i nienaruszalną godność. Tak rozumianą zasadę usieciowienia Vogt nazywa etyczną interpretacją Konferencji Narodów Zjednoczonych na temat Środowiska i Rozwoju (Szczyt Ziemi w Rio de Janeiro, 1992), podczas której szczegółowo sformułowano koncept zrównoważonego rozwoju (sustainable development) odnoszący się do wzajemnej zależności obszaru społecznego, ekonomicznego i ekologicznego (Vogt 1998).

Definicja M. Vogta jest rozwinięciem rozumienia usieciowienia W. Korffa, który nazywał je normatywną wielkością regulacyjną dla ukierunkowanego zastosowania etyki środowiska naturalnego (W. Korff 2003: 197). Usieciowienie M. Vogt ujmuje jako szczególną sieć powiązań, która obejmuje zachodzące współczesne procesy społecznogospodarcze w świetle silnej zależności człowieka od środowiska naturalnego. Merytorycznie zasada etyczna usieciowienia chce stworzyć odpowiednie struktury sprężenia zwrotnego - żąda specyficznego połączenia związków problemowych, tak żeby w maksymalnym stopniu zaprowadzić równowagę w obszarach: społeczeństwa, gospodarki 
i ekologii. Wydaje się zatem, że chodzi tutaj o synchronizację, pewną korelację, współoddziaływanie, wzajemność związku człowieka nie tylko ze społeczeństwem, gospodarką, lecz także środowiskiem przyrodniczym. Jako zasada usieciowienie ogranicza się do definiowania warunków ramowych do rozwoju współzależnych subsystemów społecznych (Vogt 1996: 170-173, za: Keppeler, 2014).

Wilfried Lochbühler nazywa usieciowienie rdzeniem kompleksowej etyki środowiska naturalnego, która znajduje swój początek w osobowej godności człowieka i w jego odpowiedzialności za przyrodę. Usieciowienie jako zasada pomostowa, łącząca etykę środowiska naturalnego z etyką społeczną, ukierunkowuje się w stronę teorii systemowej (Lochbühler 1998: 145). Systemy te jednak w perspektywie katolickiej nauki społecznej są kręgami wartości, pośród których jest także wartość środowiska przyrodniczego. Werner Veith uważa, że ta zasada etyczna jest ugruntowana antropologicznie i realizuje nowoczesne rozumienie człowieka jako podmiotu środowiska naturalnego. Usieciowienie jako kluczowa zasada ochrony środowiska naturalnego dotyczy nie tylko związku człowiek-środowisko naturalne, lecz także wydaje się ukierunkowywać na uszanowanie godności osoby ludzkiej (Veith, 2004: 307).

\section{Usieciowienie w konfrontacji z dylematami sprawiedliwości spolecznej}

Koncepcja usieciowienia nie sprowadza się jedynie do ochrony środowiska naturalnego. Pojęcie usieciowienia tłumaczy podstawową normę zrównoważonego rozwoju uwarunkowaną ekonomicznie i zasobowo w etyczną zasadę działania, która posiada wysoki potencjał istotny w różnorodnych związkach społecznych. Nowatorstwo sieciowej idei M. Vogta wynika z teorii systemów Niklasa Luhmanna i skupia się na adaptacji tzw. obszarów zbadanych w niewielkim stopniu (blinde Flecken), czyli reprodukcji wykluczonych systemów częściowych w celu ich ponownego włączenia w system sieciowy. Przez to widać, że istotą idei zrównoważonego rozwoju jest nie tylko równoważenie społecznych, ekonomicznych i ekologicznych celów rozwoju, lecz także przeciwdziałanie wykluczeniu systemów częściowych, których zniszczenie mogłoby odebrać przyszłym pokoleniom szanse realizacji ich potrzeb przez brak dostępu do zasobów naturalnych (Luhmann 1999: 634; Reis 2003: 27; Vogt 2009. 355). Podstawowe żądanie etyki zrównoważonego rozwoju pozwala się określać jako zmianę perspektyw rozwoju ze względu na związek człowieka ze środowiskiem przyrodniczym i jego odpowiedzialne działanie względem niego. Człowiek będzie mógł trwale zabezpieczyć swoją egzystencję tylko wtedy, gdy konsekwentnie będzie aktualizował swoją centralną pozycję w szerokiej sieci zależności ze środowiskiem przyrodniczym (Die deutschen Bischöfe, 1998: 118). W taki sposób, zdaniem M. Vogta, obecne pokolenie będzie wyrażać swoją solidarność wobec przyszłych pokoleń - przez takie działanie zapewnia się szanse dobrobytu przyszłym pokoleniom i teoretycznie urzeczywistnia się żądanie sprawiedliwości społecznej $\mathrm{w}$ wymiarze międzygeneracyjnym.

Koncepcja usieciowienia wskazuje na skomplikowaną strukturę problemów, których nie można rozważać oddzielnie. Pomimo wielu pytań bez odpowiedzi nie można zrezygnować z etyki odpowiedzialności, która musi sprostać wymaganiom aktualnych problemów. Według M. Vogta, w konstruowaniu zasad o wiele bardziej skuteczne jest opieranie się na koncepcji sprawiedliwości społecznej (Czekalski 2013: 57), która jest sednem definicji zrównoważonego rozwoju.

\section{W stronę etyczno-społecznej zasady zrównoważonego rozwoju}

Bez wątpienia usieciowienie stało się punktem wyjścia do stworzenia unikalnego konceptu etyczno-społecznej zasady zrównoważonego rozwoju (Nachhaltigkeitprinzip), która stanowi oryginalne połączenie usieciowienia z wymogiem sprawiedliwości społecznej i z klasycznymi 
zasadami etyczno-społecznymi wynikającymi z prawa naturalnego (Vogt 2009: 459). W chrześcijańskiej etyce społecznej usieciowienie społecznych, ekonomicznych i ekologicznych obszarów, odpowiedzialność za dzieło stworzenia, jak i sprawiedliwość międzypokoleniowa stały się konstytuującymi elementami nowej etyczno-społecznej zasady zrównoważonego rozwoju. W ten sposób ideał zrównoważonego rozwoju znalazł bardzo szybko merytoryczny oddźwięk w nauczaniu Kościoła katolickiego w Niemczech. Wydaje się, że na przestrzeni kilku lat etyczna zasada usieciowienia, zdecydowanie posiadająca charakter antropocentryczny, stała się inspiracją do wypracowania w katolickiej nauce społecznej nowej kompleksowej zasady etyczno-społecznej.

Zasada zrównoważonego rozwoju szybko została przyjęta w nauczaniu społecznym Kościoła katolickiego w Niemczech. Pojawiła się także w podręcznikach chrześcijańskiej etyki społecznej, wydanych pod redakcją Wilhelma Korffa, Reinharda Marxa i Helge Wulsdorf, a także Marianne Heimbach-Steins (Vogt 1999: 237-257; Marx, Wulsdorf 2002. 187-195; W. Veith 2004: 302-314). Najobszerniejsze opracowania nowej zasady etyczno-społecznej przedstawia dorobek naukowy monachijskiego etyka społecznego Markusa Vogta. Na gruncie katolickiej nauki społecznej zasada zrównoważonego rozwoju posiada inny status niż w chrześcijańskiej etyce społecznej (Fel, Marczak 2016: 185-205). Z punktu widzenia nowej zasady etyczno-społecznej gospodarcza eksploatacja zasobów środowiskowych podporządkowana jest prawu moralnemu, którego normy powinny regulować dynamikę procesów gospodarczych. Hierarchię celów przynależących do obszaru ekonomii i ekologii ujmowała już encyklika Quadragesimo anno, której wskazania są istotne także w perspektywie koncepcji usieciowienia i współcześnie uprawianej katolickiej nauki społecznej. „Chociaż ekonomia i etyka, każdy w swoim zakresie, własnymi się rządzą zasadami, byłoby jednak błędnym przypuszczenie, że zakresy gospodarczy i moralny tak są różnorodne i obce sobie, że żadna pomiędzy nimi nie zachodzi zależność. Wszakże z istoty dóbr ziemskich i z istoty człowieczej, cielesnej i duchowej, wywodzą się tak zwane gospodarcze, ustalające, które cele i jakimi środkami przez człowieka w dziedzinie gospodarczej nieosiągnięte lub osiągnięte być mogą. Z tej samej natury dóbr rzeczowych i z tej samej istoty człowieczej, indywidualnej i społecznej, wysnuwa i rozum ludzki z całą pewnością ostateczny cel, który Bóg Stwórca, wytknął całemu życiu gospodarczemu. Ale jedno jest prawo moralne, które nakłada na nas obowiązek, abyśmy we wszystkich poczynaniach naszych do najwyższego i ostatecznego dążyli celu, ale również i w poszczególnych dziedzinach poczynania naszego do tych zmierzali celów, które im natura albo raczej Stwórca natury, Bóg, jak wiemy, wykreślił, i uporządkowawszy je, poddali owemu celowi ostatecznemu. Jeśli od tego uzależni się prawa, zajmą cząstkowe cele gospodarcze i poszczególnych osób i całego społeczeństwa należyte miejsce w wszechświatowej hierarchii celów, my zaś wstępować będziemy po nich, jakoby po stopniach, do ostatecznego celu wszechrzeczy, do Boga, który jest i dla Siebie, i dla nas dobrem najwyższym i niewyczerpanym" (Pius XI: 42-43). W taką hierarchię celów i związek gospodarki z prawem moralnym wpisuje się system zasad etyczno-społecznych, z którego potencjału wyłaniane są nowe, szczegółowe zasady etyczno-społeczne, odpowiadające na współczesne problemy życia społeczno-gospodarczego, pośród których pojawiła się problematyka degradacji środowiska przyrodniczego. Kwestia ekologiczna wymaga bowiem szczegółowych wskazań organizacyjnych ujmujących związek człowieka ze środowiskiem przyrodniczym.

Zasada zrównoważonego rozwoju stała się przedmiotem zainteresowania w środowisku niemieckich etyków społecznych, czego potwierdzeniem była polemika pomiędzy Markusem Vogtem i Bernhardem Sutorem na łamach czasopisma "Stimmen der Zeit” (Sutor 2012: 624; Sutor 2013: 228-229; Vogt 
2016: 137-138). Polemika M. Vogta z B. Sutorem miała miejsce w kontekście swoistej profesjonalizacji katolickiej nauki społecznej i jej rozczłonkowania na specjalistyczne etyki szczegółowe koncentrujące się na wąskich obszarach życia społecznego. Wśród nich, oprócz etyki gospodarki, etyki mediów, etyki rozwoju czy etyki polityki, wyłoniła się etyka społeczna zajmująca się kwestią ekologii (Ökologische Sozialethik). Wszystkie wymienione etyki obszarowe, wraz z etyką indywidualną i etyką społeczną, wchodzą w zakres etyki normatywnej (lub etyki stosowanej), która analizuje w aspekcie etycznym konkretne obszary działania. Każdemu z nich odpowiada koherentny system zasad etyczno-społecznych, silnie potencjalny, zdolny generować szczegółowe zasady działania społecznego wpisujące się w wymiar dobra wspólnego i kategorie sprawiedliwości społecznej. W kwestii ekologicznej takim principium społecznym jest zasada zrównoważonego rozwoju, która w klasyfikacji systemu principiów społecznych Władysława Piwowarskiego wyraża szczegółową zasadę sprawiedliwości społecznej ujmującą organizację działania ludzkiego w życiu społecznym. Nowe principium społeczne stoi na straży godności osoby ludzkiej i służy hierarchizacji celów we współzależnych systemach społecznych, gospodarczych i ekologicznych. Koncepcja usieciowienia wniosła istotny wkład w genezę zasady zrównoważonego rozwoju i jakościowe rozszerzenie systemu zasad etyczno-społecznych na gruncie katolickiej nauki społecznej.

Peter Schallenberg i Marius Menke zauważają nową zasadę etyczno-społeczną na gruncie katolickiej nauki społecznej i określają ją jako jakościowe rozszerzenie systemu zasad etyczno-społecznych (Schallenberg, Menke, 2016: 173-174). Zasada zrównoważonego rozwoju stawia we wzajemnym tematycznym związku dotychczas uznane w chrześcijańskiej etyce społecznej zasady personalizmu, solidarności i pomocniczości, łącząc ze sobą przypisane im wymiary. Peter Schallenberg i Marius Menke podkreślają, że reakcją na kryzys ekologiczny wraz z zasadą zrównoważonego rozwoju jest kształtowanie się nowego chrześcijańskiego etosu odpowiedzialności za przyszłe pokolenia. W dyskusji o zrównoważonym rozwoju na gruncie katolickiej nauki społecznej krystalizuje się także czysty, metodyczny antropocentryzm. Z jednej strony, w życiu społecznym człowiek pozostaje celem ostatecznym, z drugiej strony, jest zależny od zasobów środowiska przyrodniczego, do którego dostęp określają granice jego egzystencji (Schallenberg, Menke, 2016: 174).

Włączenie perspektywy międzypokoleniowej sprawiedliwości społecznej świadczy o ewolucji katolickiej nauki społecznej, która raczej w klasycznym ujęciu bardziej jest zorientowana na realizację sprawiedliwości wewnątrzpokoleniowej w wymiarze społeczno-gospodarczym. Niemniej wyłonienie się kwestii ekologicznej, potwierdzone pierwszą encykliką społeczną o charakterze ekologicznym Laudato si', stało się przedmiotem zainteresowania przedstawicieli szkół zajmujących się katolicką nauką społeczną. Stanowisko M. Vogta odnośnie racji rozszerzenia systemu zasad etyczno-społecznych o zasadę zrównoważonego rozwoju zostało potwierdzone decyzją fundacji "Centesimus Annus - Pro Ponfefice”, która 20 maja 2017 r. na Watykanie, przed gronem blisko dwustu osób zajmujących się katolicką nauką społeczną, przyznała monachijskiemu etykowi wyróżnienie za dokonania w przestrzeni kształtowania życia społeczno-gospodarczego zawarte głównie w publikacji Prinzip Nachhaltigkeit. Ein Entwurf aus theologisch-ethischer Perspektive (Web-01).

\section{Zakończenie}

„Teraźniejszość i przyszłość świata zależą od ochrony rzeczywistości stworzonej, ponieważ człowiek i przyroda nieustannie oddziałują na siebie nawzajem" (Jan Paweł II 1999). Te słowa Jana Pawła II wskazują na odpowiedzialność za środowisko naturalne, którego troskliwe zachowanie jest wyrazem solidarności z ludźmi, którzy nadejdą po nas. Uznanie zasadą, że najważniejszym 
motywem troski o środowisko naturalne jest dobro samego człowieka, staje się najpewniejszą gwarancją ochrony dzieła stworzenia (Jan Paweł II 1999). Wydaje się, że w takie rozumienie odpowiedzialności za środowisko naturalne wpisuje się koncepcja usieciowienia, która w ujęciu M. Vogta jest istotą etyki zrównoważonego rozwoju i jednocześnie zasadą etyczną nadającą środowisku naturalnemu wyższą wartość. Usieciowienie jest zasadą pomostową, integrującą człowieka z obszarem społecznym, gospodarczym i ekologicznym. Przez integrację z konceptem sustainable development, który zdecydowanie ma charakter politycznego działania, usieciowienie wydaje się być etyczną kategorią interpretacyjną zrównoważonego rozwoju.

Na gruncie chrześcijańskiej etyki społecznej w Niemczech usieciowienie stało się rdzeniem nowej zasady etyczno-społecznej zrównoważonego rozwoju, która łączy w sobie klasyczne zasady społeczne katolickiej nauki społecznej, stojące na straży godności osoby ludzkiej, zapewniające człowiekowi niezbędne prawa do życia i integralnego rozwoju nie tylko w perspektywie obecnych pokoleń, lecz także przyszłych. Koncepcja usieciowienia wyrażona w zasadzie zrównoważonego rozwoju jest podstawowym warunkiem realizacji sprawiedliwości społecznej i jednocześnie przyszłościowym, solidarnym organizowaniem społeczeństwa, w którym coraz bardziej wydaje się ukazywać konieczność nieustannego wyważania sprawiedliwych warunków ramowych służących w odległej perspektywie zapewnieniu szans dobrobytu przyszłym pokoleniom przez dostęp do zasobów środowiskowych.

\section{Bibliografia}

Becker E., Jahn T., 2006, Soziale Ökologie. Grundzüge einer Wissenschaft von den gesellschaftlichen $\mathrm{Na}$ turverhältnissen, Campus Verlag, Frankfurt-New York.

Benedykt XVI, 2009, Enc. "Caritas in veritate" (29.06.2009), Wydawnictwo Biblos, Tarnów.
Birnbacher D., 2009, Odpowiedzialność za przyszłe pokolenia - zakres i granice, Studia Ecologiae et Bioethicae, 1, 90-106.

Bornhold S., Feindt P.H., 1996, Komplexe adaptive Systeme, Max-Planck-Gesellschaft, Dettelbach.

Czekalski R., 2013, Marcusa Vogta próba integracji zasad ekorozwoju z Katolicka Nauka Społeczna, Studia Ecologiae et Bioethicae, 2, 47-63.

Deutscher Bundestag. Rat von Sachverständigen für Umweltfragen, 1994, Für eine dauerhaft-umweltgerechte Entwicklung. Umweltgutachten 1994 des Rates von Sachverständigen für Umweltfragen (12/6995), Bonn.

Die deutschen Bischöfe, 1998, Kommission für gesellschaftliche und soziale Fragen, Handeln für die Zukunft der Schöpfung, Bonn.

Heimbach-Steins M., Lienkamp A., 2007, Zukunft in Solidarität und Gerechtigkeit. Eine Relecture des Wirtschafts-und Sozialwortes der Kirchen nach zehn Jahren, Stimmen der Zeit, 7, 457-470.

Jan Paweł II, Poszanowanie praw człowieka warunkiem prawdziwego pokoju. Orędzie na XXXII Światowy Dzień Pokoju (1.01.1999).

Jeżowski P., 2012, Rozwój zrównoważony i jego nowe wyzwania, Kwartalnik Kolegium Ekonomiczno-Społecznego Studia i Prace, 2, 99-124.

Keppeler C., 2014, Perspektivische Personalführung. Die katholische Soziallehre als Grundlage für eine zeitgemäße Führungskultur, Tectum Verlag, Marburg.

Korff W. 2003 „Die Schöpfung hat Gott im Rücken und vor sich". Wilhelm Korff im Gespräch mit Wolfgang Küpper, w: Bachleitner G., Wingen W. (red.), Moderne im Umbruch. Fragen nach einer zukunftsfähigen Ethik. Sozialethisches Symposium zum 75. Geburstag von Wilhelm Korff, Verlag Herder, Freibourg-Freiburg-Wien, 176-211.

Korff W., 1989, Leitideen verantworteter Technik, Stimmen der Zeit, 4, 253-266.

Korff W., 1991, Wirtschaft vor den Herausforderungen der Umweltkrise, w: Bischöfliches Ordinariat Essen, Zur christlichen Berufsethik - Kirche im Gespräch, Essen, 9-36.

Lienkamp A., 2009, Klimawandel und Gerechtigkeit. Eine Ethik der Nachhaltigkeit in christlicher Perspektive, Ferdinand Schöningh, Padeborn.

Lochbühler W., 1998, „Nachhaltige Entwicklung”: Eine Herausforderung für die christliche Sozialethik, Theologie der Gegenwart", 2, 138-149. 
Luhmann N., 1999, Die Geselschaft der Geselschaft, Suhrkamp Taschenbuch Wissenschaft, Frankfurt a. M.

Mariański J., 2003, Troska Kościoła o ochronę środowiska, w: Kupny J., Fel S. (red.), Katolicka nauka społeczna. Podstawowe zagadnienia z życia gospodarczego, Księgarnia św. Jacka, Warszawa, 202-218.

Marx R., Wulsdorf H., 2002, Christliche Sozialethik. Konturen - Prinzipien - Handlungsfelder, Bonifatius, Padeborn.

Nell-Breuning O., 1985, Gerechtigkeit und Freiheit. Grundzüge katholischer Soziallehre, Günter Olzog Verlag, München.

Raport Brundtland (Nasza wspólna przyszłość), 1987, Światowa Komisja Środowiska i Rozwoju ONZ.

Rat der Evangelischen Kirche in Deutschland und der Deutschen Bischofskonferenz, 1997, Für eine Zukunft in Solidarität und Gerechtigkeit, Hannover-Bonn.

Reis O., 2003, Nachhaltigkeit-Ethik-Theologie. Eine theologische Beobachtung der Nachhaltigkeitsdebatte, LIT Verlag, Münster.

Schallenberg P., Menke M., 2016, Die Enzyklika "Laudato si" und die katholischen Soziallehre, Die Neue Ordnung, 70, 3, 164-178.

Sutor B., 2012, Nachhaltigkeit - ein neues Sozialprinzip?, Stimmen der Zeit, 9, 617-625.

Sutor B., 2013, Katholische Soziallehre als politische Ethik. Leistungen und Defizite, Ferdinand Schöningh, Paderborn.

Veith W., Nachhaltigkeit, 2004, w: Heimbach-Steins M. (red.), Christliche Sozialethik, Verlag Friedrich Pustet, Regensburg, 302-314.
Vogt M., 1996, Retinität: Vernetzung als ethisches Leitprinzip für das Handeln in komplexen Systemzusammenhängen, w: Bornhold S., Feindt Roll P.H. (red.), Komplexe adaptive Systeme, Dettelbach, 159-197.

Vogt M., 1998, Ratinität, w: Korff W. (red.), Lexikon der Bioethik, Band 3, Gütersloher Verlaghaus, Gütersloh, 209-210.

Vogt M., 1999, Das neue Sozialprinzip „Nachhaltigkeit" als Antwort auf die ökologische Herausforderung, w: Korff W. (red.), Handbuch der Wirtschaftsethik, Band 1, Gütersloher Verlagshaus, Gütersloh, 237-257.

Vogt M., 2009, Prinzip Nachhaltigkeit. Ein Entwurf aus theologisch-ethischer Perspektive, Oekom Verlag, München.

Vogt M., 2016, Nachhaltigkeit als neues Sozialprinzip christlicher Ethik, w: Patenge M., Beck R., Luber M. (red.), Schöpfung bewahren. Theologie und Kirche als Impulsgeber für eine nachhaltige Entwicklung, Verlag Friedrich Pustet, Regensburg, 128-149.

Zabłocki G., 2002, Rozwój zrównoważony - idee, efekty, kontrowersje, Uniwersytet Mikołaja Kopernika, Toruń.

(Web-01) Fondazione Centesimus Annus - Pro Ponfefice, Third Edition of the International Prize for "Economy and Society" Palazzo della Cancelleria, Rome, 18th May 2017, Speech by the Secretary of State H.E. Cardinal Pietro Parolin, http://www. centesimusannus.org/media/premio_centesimus_ annus_2017\%2oEN\%2o(final).pdf, dostęp 5.12.2017.

\title{
The networking concept as an ethical interpretative key of the sustainable development principle
}

\begin{abstract}
The aim of the study is to present the concept of networking (Retinität), developed on the basis of Christian social ethics, which has become a key to the interpretation of the sustainable development principle. The article presents a network based on the Munich social ethics of Markus Vogt, who recognises this concept in Christian social ethics as a fundamental strategy of action to protect the natural environment, also affecting the dynamics of economic processes. Retinität has become one of the determinants of choosing the sustainable development principle on the basis of Christian social ethics as a result of the analysis of ethical and social principles systems.
\end{abstract}

\section{Keywords}

networking, sustainable development, Catholic social thought, Catholic social ethics 